NBER WORKING PAPER SERIES

\title{
LABOR MARKET FRICTIONS AS A SOURCE OF COMPARATIVE ADVANTAGE, WITH IMPLICATIONS FOR UNEMPLOYMENT AND INEQUALITY
}

\author{
Elhanan Helpman \\ Working Paper 15764 \\ http://www.nber.org/papers/w15764 \\ NATIONAL BUREAU OF ECONOMIC RESEARCH \\ 1050 Massachusetts Avenue \\ Cambridge, MA 02138 \\ February 2010
}

I thank Oleg Itskhoki and Stephen Redding for comments, Jane Trahan for editorial assistance, and the National Science Foundation for financial support. The views expressed herein are those of the author and do not necessarily reflect the views of the National Bureau of Economic Research.

NBER working papers are circulated for discussion and comment purposes. They have not been peerreviewed or been subject to the review by the NBER Board of Directors that accompanies official NBER publications.

(C) 2010 by Elhanan Helpman. All rights reserved. Short sections of text, not to exceed two paragraphs, may be quoted without explicit permission provided that full credit, including $\odot$ notice, is given to the source. 
Labor Market Frictions as a Source of Comparative Advantage, with Implications for Unemployment and Inequality

Elhanan Helpman

NBER Working Paper No. 15764

February 2010

JEL No. F12,F16,J64

\section{ABSTRACT}

Recent research has emphasized firm heterogeneity as a source of comparative advantage. Combining this approach with labor market frictions and worker heterogeneity provides a framework for studying the impact of trade on unemployment and inequality. This paper reviews this approach and reports a number of results from recent studies.

Elhanan Helpman

Department of Economics

Harvard University

1875 Cambridge Street

Cambridge, MA 02138

and NBER

ehelpman@harvard.edu 


\section{Introduction}

Until the 1980s, studies of international trade were dominated by two sources of comparative advantage: technological capabilities and factor endowments. The former approach, originally attributed to David Ricardo, starts from the observation that sectoral relative labor productivity varies across countries, and derives from this feature implications for the structure of foreign trade. The latter approach, originally attributed to Eli Heckscher and reformulated by Bertil Ohlin, starts from the observation that endowments vary across countries, and derives from this feature implications for the structure of trade, assuming that technologies are the same in every country. While the Ricardian approach abstracts from differences in the composition of factor endowments, the Heckscher-Ohlin approach abstracts from differences in technologies. These two approaches are complementary to each other, emphasizing alternative sources of comparative advantage. Both focus, however, on explaining the structure of trade at the sectoral level; that is, on predicting which country exports food, which exports electronic products, which exports chemical products, and so forth.

As growth in world trade proceeded at a rapid pace after World War II, and especially so in manufactures, it became apparent that this focus was not adequate, because much of world trade was taking place within industries. Namely, many countries both exported and imported food, exported and imported electronic products, and exported and imported chemical products. Moreover, it was recognized that an emphasis on differences across countries, either in technologies or factor endowments, is useful for explaining trade among countries which differ from each other, but not for explaining trade among countries that are similar to each other. Yet the majority of world trade took place (and still does) among the industrial countries, which are similar to each other, rather than between the industrial and less developed countries, which differ substantially.

In response to these empirical observations the analysis of trade was further enriched in the 1980s with the development of trade models that featured economies of scale and imperfect competition. Particularly successful was the integration of monopolistic competition into an otherwise standard Heckscher-Ohlin framework, thereby accounting for the existence of both intersectoral and intra-industry trade, and for large volumes of trade among similar countries. Over time, the resulting Helpman-Krugman model became the standard tool for addressing trade issues, such as the link between trade and growth, because it proved to be flexible enough for both theoretical and empirical analysis.

Despite the desirable features of the trade models from the 1980s, they turned out to be inadequate for explaining a range of new findings that emerged in the 1990s. In that decade new firm-level data sets became available, which led to the discovery of new patterns of trade within industries. Of particular interest was the finding that within a sector, such as food or electronics, only a fraction of firms export, and that this fraction varies greatly 
across industries. Moreover, within an industry, exporting firms differ systematically from nonexporters; in particular, exporters are bigger and more productive than nonexporters, they employ a different composition of workers, and they pay higher wages. These findings led to a reexamination of the monopolistic competition approach to international trade, enriching it with heterogeneous firms within industries and to a new workhorse for trade analysis, the Melitz model.

In parallel, both theory and empirical analysis started to pay more attention to institutional determinants of comparative advantage. Scholars incorporated incomplete contracts into trade theory in order to study firm choices between outsourcing and inhouse production of intermediate inputs on the one hand and offshoring versus domestic sourcing of intermediate inputs on the other. ${ }^{1}$ This brought to the fore the role of legal institutions in shaping comparative advantage. Indeed, differences across countries in the quality of legal systems proved to be an important determinant of trade flows. ${ }^{2}$ Other studies examined the role of financial institutions in shaping world trade, and found that differences across countries in level of financial development had a large impact on trade flows, and this effect was related to variation across sectors in the degree of dependence on external finance. ${ }^{3}$ Finally, differences across countries in labor market characteristics shape trade structure, by impacting the degree to which it pays a country to lock in resources in industries with different volatility levels. $^{4}$

The addition of within-industry heterogeneity and institutional factors to the toolkit of international trade analysis has enriched our ability to understand new sources of comparative advantage and, as a result, new developments in international trade and foreign direct investment. It is not my intention to review all these developments, but rather to discuss one line of inquiry in which heterogeneity within industries and differences across countries in labor market frictions play a central role. For this purpose I first review some of the insights from Melitz (2003) on trade with heterogeneous firms, followed by a discussion of search and matching frictions in labor markets - which have been introduced into the literature by Diamond (1982a,b) and Mortensen and Pissarides (1994). Finally, I discuss the work of Helpman and Itskhoki (2009) and Helpman, Itskhoki and Redding (2009, 2010), which combine search and matching frictions in labor markets with Melitz-style firm heterogeneity in order to investigate the determinants of unemployment and inequality in trading countries. This discussion is organized around the following three questions: (i) What are the impacts of one country's labor market frictions on its trade partner? (ii) How does removing trade impediments impact countries with different labor market frictions? and (iii) What is the

\footnotetext{
${ }^{1}$ See Helpman (2006) for a review of this literature.

${ }^{2}$ Nunn (2007) in particular finds that the quality of legal institutions is at least as important as human capital in explaining the structure of exports.

${ }^{3}$ See Manova $(2008,2009)$.

${ }^{4}$ See Cuñat and Melitz (2007).
} 
impact of trade on inequality and unemployment?

\section{Heterogeneous Firms within Industries}

As pointed out above, in the 1990s a number of studies examined how firms differ by trade status. Bernard, Jensen and Lawrence (1995) and Bernard and Jensen (1999) addressed this question with U.S. data, and their work was followed by studies based on data from Canada, Colombia, France, Mexico, Morocco, Spain and Taiwan. ${ }^{5}$ All these studies found that only a small fraction of firms export, that exporting firms are larger and more productive than nonexporters, and that firms exhibit persistence in their export status; namely, nonexporters persist in not exporting while exporters persist in exporting, although occasionally firms switch status. The last finding was interpreted to reflect the sunk costs of exporting, meaning that a firm has to bear a fixed cost in order to penetrate a foreign market. ${ }^{6}$ Das, Roberts and Tybout (2007) found such costs to be around $\$ 400,000$ for Colombian firms.

According to the World Trade Organization (2008, Table 5), in the United States 18 percent of manufacturing firms exported in 2002, in France 17.4 percent of firms in this sector exported in 1986, in Japan this fraction was 20 percent in 2000, and in Norway it exceeded 39 percent in 2003. The same publication (2008, Table 6) reports a high concentration of exports in large firms. In the United States, for example, in 2002 the top 1 percent of firms by size controlled 81 percent of manufacturing exports, while the top 10 percent controlled 96 percent. In France the comparable numbers were 44 and 84 percent, respectively, in 2003, and in Norway they were 53 and 91 percent, respectively, in 2003.

Exporting firms are both larger and more productive than nonexporters. For example, in the United States exporters employ about twice as many workers as nonexporters, and the value-added per worker of exporters is 11 percent larger than the value-added per worker of nonexporters. ${ }^{7}$ Nevertheless, exporting firms sell abroad only a small fraction of their output. ${ }^{8}$

Melitz (2003) develops a theoretical framework that can explain these data. His point of departure is a sector in which firms engage in monopolistic competition and produce a large assortment of brands of a differentiated product, as in the Helpman-Krugman model. Unlike Helpman-Krugman, however, Melitz assumes that an entrant to the industry faces uncertainty regarding its total factor productivity. Upon bearing the entry cost a firm learns the productivity of its technology, yet before entry all it knows is the distribution from which

\footnotetext{
${ }^{5}$ See Baldwin and Gu (2003) for Canada; Clerides, Lach and Tybout (1998) for Colombia, Mexico and Morocco; Bernard, Eaton, Jensen and Kortum (2003) and Eaton, Kortum and Kramarz (2004) for France; Delgado, Fariñas and Ruano (2002) for Spain; and Aw, Chung and Roberts (2000) for Taiwan.

${ }^{6}$ See Roberts and Tybout (1997) for Colombia and Bernard and Jensen (2004) for the United States.

${ }^{7}$ See Bernard, Jensen, Redding and Schott (2007, Table 3) for estimates with industry fixed effects.

${ }^{8}$ See Bernard, Jensen, Redding and Schott (2007, Table 2).
} 
its productivity level will be drawn. For this reason, to evaluate the profitability of entry, a firm has to form strategies conditional on every conceivable productivity draw: whether it will stay in the industry and bear the fixed cost of production, whether it will serve only the domestic market, or whether in addition to serving the domestic market it will also export and bear the fixed cost of exporting. In what follows I focus on a two-country world, so that a firm does not need to choose to which countries to export - only whether to export or notand it cannot engage in foreign direct investment. ${ }^{9}$ After forming these contingent plans, a firm faces a distribution of profits at the entry stage and it enters only if the expected profits are sufficiently high to cover the entry cost. In a free-entry equilibrium, expected profits just equal the entry cost. This is the economic structure modelled by Melitz (2003).

Firms produce output according to the production function

$$
y=\theta h,
$$

where $y$ is output, $\theta$ is productivity - drawn from a known cumulative distribution $G(\theta)$ and $h$ is labor employment. This production function applies to every variety of the product. Preferences are CES with the elasticity of substitution $\varepsilon$. The fixed production cost is $f_{d}$, the fixed export cost is $f_{x}$, and the fixed entry cost is $f_{e} \cdot{ }^{10}$ In addition, there are variable trade costs, summarized by the parameter $\tau>1 ; \tau-1$ measures the fraction of extra costs, due to tariffs or shipment outlays, that an exporter has to bear in order to deliver a product to the foreign country. From this specification it is possible to compute operating profits from serving only the domestic market as a function of productivity, denoted $\pi_{d}(\theta)$, and the combined profits from both serving the domestic market and from exporting (net of the fixed costs of production and exporting) as a function of productivity, denoted $\pi_{d+x}(\theta)$. As a result, the highest attainable profit level as a function of productivity is $\pi(\theta)=\max \left\{0, \pi_{d}(\theta), \pi_{d+x}(\theta)\right\}$, and the free-entry condition is

$$
\int_{0}^{\infty} \pi(\theta) d G(\theta)=f_{e}
$$

It is clear from this exposition that if the lowest value of $\theta$ in the support of $G(\cdot)$ is low enough, then there exists a productivity cutoff $\theta_{d}$ - the domestic cutoff-at which $\pi_{d}\left(\theta_{d}\right)=0$; that is, firms with this productivity break even by serving the domestic market only. Firms with productivity above this cutoff have no reason to leave the industry because they make profits after entry. In addition, whenever

$$
\tau^{\varepsilon-1} f_{x}>f_{d}
$$

\footnotetext{
${ }^{9}$ See, however, Helpman, Melitz and Yeaple (2004) for multiple countries with FDI, and Helpman, Melitz and Rubinstein (2008) for multiple countries and the choice of exporting to only some of them.

${ }^{10}$ Melitz (2003) analyzes a dynamic model, while I use a static version in this paper. For this reason I do not distinguish between fixed costs and the sunk cost of entry.
} 


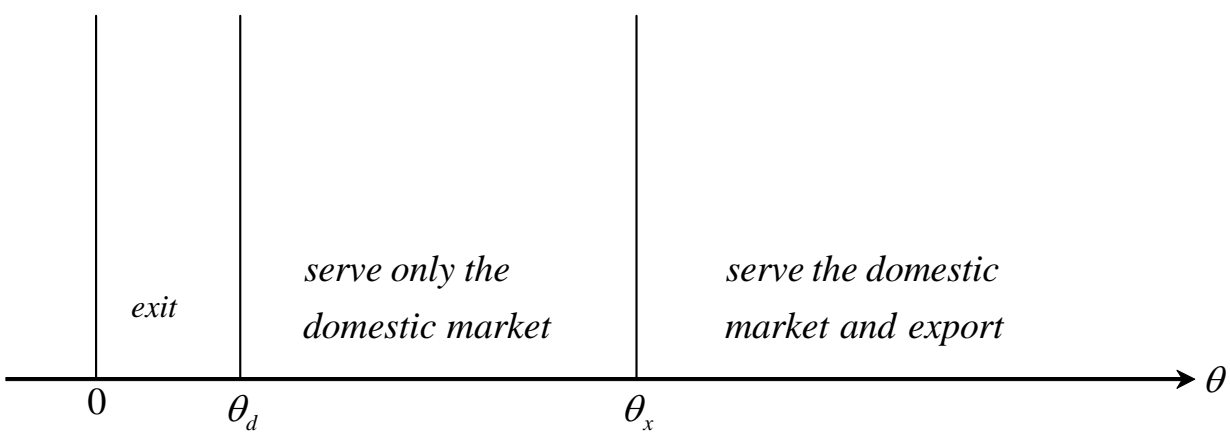

Figure 1: Optimal strategies for firms with different productivity levels

there also exists an export cutoff, $\theta_{x}$, at which profits from serving the domestic market just equal profits both from serving the domestic market and from exporting, i.e., $\pi_{d}\left(\theta_{x}\right)=$ $\pi_{d+x}\left(\theta_{x}\right)$, such that $\theta_{x}>\theta_{d}$. Under these circumstances the optimal strategies of firms are represented in Figure 1: the lowest productivity firms, with $\theta<\theta_{d}$, exit the industry, those with productivity $\theta_{d}<\theta<\theta_{x}$ stay and serve only the domestic market, and those with $\theta>\theta_{x}$ stay and serve both the domestic and the foreign market.

This sorting pattern is consistent with the evidence. First, only a fraction of firms export. Second, exporters sell only a portion of their output to foreign customers. Third, exporters are more productive and larger than nonexporters. ${ }^{11}$ And finally, the distribution of export sales is skewed toward larger firms. This analysis offers a simple explanation of these patterns in the data, but it does not explain why exporters pay higher wages than nonexporters, because it assumes that the labor market is competitive and therefore all firms pay the same wages. As a result, there is no wage inequality among workers.

This framework is also useful for understanding episodes of trade liberalization. Balassa $(1966,1967)$ was the first to note that the formation of the European Common Market did not lead to major reallocations of resources across industries, as would be predicted by traditional Ricardian or Heckscher-Ohlin trade theory, but rather to large reallocations within industries. And more recent studies of trade liberalization, which use detailed firmlevel data - such as Tybout and Westbrook (1995) for Mexico, Pavcnik (2002) for Chile, and Trefler (2004) for Canada - find large market share reallocations within industries from lowto high-productivity firms, and the exit of low-productivity firms.

To see how the Melitz model can explain these findings, consider a reduction in $\tau$. This raises profits from export sales, which leads to an expansion of output by exporters and thereby to a shift in market share from firms that do not export to exporters. The expansion

\footnotetext{
${ }^{11}$ They are larger because higher-productivity firms employ more workers, produce more goods, and thus have higher revenue.
} 
of exporting firms raises demand for domestic factors of production and leads to a hike in wages relative to product prices, thereby reducing the profitability of all firms, exporters and nonexporters alike. As a result, the profits of nonexporters decline, and those who are least productive and barely breaking even lose money after trade liberalization and exit the industry. On the other side, while higher input costs reduce the profits of exporters, this reduction is not sufficient to fully offset the initial rise in their profitability as a result of the decline in variable trade costs. Therefore, the final outcome is exit of the least productive firms and market share reallocation from low-productivity domestic firms to high-productivity exporters. This reallocation of resources within the industry raises the industry's average productivity.

I will use these insights in the analysis of the interdependence of countries with different levels of labor market frictions. But first I discuss the nature of the labor market frictions that will be used in this analysis.

\section{Search and Matching Frictions in Labor Markets}

To understand the relationship between trade and unemployment, we need to explicitly formulate frictions that lead to unemployment in the first place. For this purpose Helpman and Itskhoki (2009) and Helpman, Itskhoki and Redding (2009, 2010) use the DiamondMortensen-Pissarides search and matching framework for labor markets, which is described in detail in Pissarides (2000). While the Diamond-Mortensen-Pissarides framework is dynamic, it was adapted to static models in the Helpman-Itskhoki-Redding studies. However, our static framework represents the steady state of a dynamic model.

Imagine a labor market in which workers match with firms and the number of successful matches depends on how many workers search for jobs and how many vacancies are posted by firms; the more workers search for jobs or the more vacancies are posted the larger the number of successful matches. This relationship is represented by a matching function, assumed to take the Cobb-Douglas form

$$
H=m V^{\chi} N^{1-\chi}, \quad 0<\chi<1,
$$

where $H$ is the number of successful matches, $V$ is the number of vacancies, and $N$ is the number of workers searching for jobs. The parameter $m$ measures the efficiency of the matching processes, while $\chi$ measures the weight of vacancies in the matching function. In this representation the details of the matching process are not spelled out, yet the matching function is assumed to represent the outcome of this process. This choice of functional form is not arbitrary, however, because it fits the data well.

In the dynamic version of the model, $V$ and $N$ are stocks while $H$ is a flow. As a 
result, the ratio $H / N$ is a hazard rate, representing the instantaneous probability (per unit time) that a worker finds employment. In the static version of the model to be considered here, $H / N$ simply represents the probability that a worker finds employment, and we treat this probability as a measure of labor market tightness, to be denoted by $x$. Similarly, the probability that a firm that posts a vacancy finds a worker equals $H / V$. Therefore, if $v$ denotes the cost of posting a vacancy, then the expected cost of hiring a worker is $b \equiv v V / H$, i.e., it equals the cost of a vacancy divided by the probability of finding a worker per vacancy posted. We refer to $b$ as the cost of hiring, and the matching function implies that it equals

$$
b=\frac{1}{2} a x^{\alpha}, \quad \text { where } a \equiv \frac{2 v}{m^{1+\alpha}} \text { and } \alpha \equiv(1-\chi) / \chi .
$$

The derived parameter $a$ summarizes labor market frictions; it rises with the cost of posting vacancies, $v$, and declines with the efficiency of the matching process, $m$. In an economy with multiple sectors, equation (3) is sector-specific; it represents a relationship between the tightness of the sector's labor market and the sector's cost of hiring.

Workers choose in which sector to search for jobs. Once a worker has committed to a sector, however, his chance of being matched with a firm equals the ratio of hires in the sector, $H$, to the number of workers searching for jobs in this sector, $N$. And the probability that a firm fills a posted vacancy equals the sectoral ratio $H / V$. We allow both the cost of vacancies, $v$, and the efficiency of matching, $m$, to vary across sectors, but - for simplicity - assume that $\chi$ is the same in every industry, and therefore so is $\alpha$. Under the circumstances our measure of labor market frictions, $a$, also varies across sectors, reflecting differences in the efficiency of matching and vacancy costs.

As described above, a worker chooses in which sector to search for a job, and the probability of finding employment may differ across sectors. In addition, the wage rate may differ across sectors. Therefore, risk-neutral workers choose to search for work in the sector that yields the highest expected wage rate. ${ }^{12}$ For now assume that being matched with a firm secures employment and that all employed workers in a sector are paid the same wage rate (as will be the case in Section 4 but not in 5). Then a worker chooses the sector with the highest value of $x w$, where $x$ is the sector's labor market tightness and $w$ is the sector's wage rate. In equilibrium, $x w$ obtains the same value in all sectors in which workers search for jobs. In other words, there exists an expected income $\omega$ that represents the outside option of a worker who chooses in which sector to search for a job, and in equilibrium

$$
x w=\omega
$$

\footnotetext{
${ }^{12}$ I focus on risk-neutral workers. See, however, the appendix in Helpman and Itskhoki (2009) for a formulation with risk-averse individuals.
} 
in every sector with a positive number of workers. ${ }^{13}$ After the matching process ends, every firm bargains with its workers over wages.

\section{Trade and Interdependence}

In this section I describe a number of results on trade and interdependence that are developed in Helpman and Itskhoki (2009). Their model features two countries that are alike except for frictions in their labor markets. There are two sectors, one producing a homogeneous product under constant returns to scale - with one unit of output per worker - the other producing varieties of a differentiated product. Each sector has labor market frictions of the type described in the previous section, with the coefficient $a$ varying across sectors and countries. The countries are indexed by $A$ and $B, a_{0 j}$ denotes the coefficient of labor market frictions in the homogeneous sector of country $j$, and $a_{j}$ denotes the coefficient of labor market frictions in the differentiated sector of country $j$. For concreteness it is assumed that $a_{A} / a_{0 A}>a_{B} / a_{0 B}$, so that country $B$ has relatively lower labor market frictions in the differentiated sector. This implies $b_{A}>b_{B}$; that is, the cost of hiring in the differentiated sector is larger in country $A$, as I explain below. The homogeneous sector serves as numeraire, so that the price of the homogeneous product equals one and all costs are measured in units of this good.

Every country is populated by a continuum of representative families, with each family having a continuum of members who are workers. A family's preferences are quasi-linear, with the marginal utility of the homogeneous good being constant and equal to one. As a result, families are risk-neutral and each family allocates its workers across sectors to maximize the family's income, which is not random due to the law of large numbers. ${ }^{14}$

In the homogeneous sector every firm matches with a single worker and firms enter the industry until the expected profits equal the entry cost, with the latter being the cost of posting a vacancy, $v_{0}$. When a worker and a firm match they split equally the surplus from the relationship, which equals 1 . As a result, the wage rate equals $1 / 2$ in the homogeneous sector and so does the cost of hiring, i.e., $w_{0 j}=b_{0 j}=1 / 2$. Under these circumstances the free-entry condition pins down uniquely the level of tightness in the sector's labor market, i.e., $x_{0 j}=a_{0 j}^{-1 / \alpha}$, and therefore the outside option of workers searching for jobs in the differentiated sector is $\omega=a_{0 j}^{-1 / \alpha} / 2$. In other words, the higher the frictions in the homogeneous sector's labor market are, the worse is the outside option of workers searching for jobs in the differentiated sector. Using this value of $\omega$, equations (3) and (4) provide solutions to the hiring cost and market tightness in the differentiated sector. Note that $b_{j}$ and $x_{j}$ depend on labor market frictions but not on trade frictions. As a result, both a closed and an open economy have equally tight labor markets, the same hiring costs, and the same wage rates,

\footnotetext{
${ }^{13}$ In this equation $x$ and $w$ are sector-specific while $\omega$ is the same for all sectors.

${ }^{14}$ See, however, the appendix in Helpman and Itskhoki (2009) for a treatment of risk-averse workers.
} 
measured in units of the homogeneous good. Real wages are not the same in a closed and open economy, however, as argued below.

The differentiated sector is structured in the same way as in the model described in Section 2, except for the labor market frictions. In particular, firms enter the industry after bearing a fixed entry cost, $f_{e}$. Upon entry a firm learns its productivity level $\theta$ that is drawn from a known distribution, $G(\theta)$. Once it knows its productivity it has to decide whether to stay in the industry and bear the fixed cost of production, $f_{d}$ or exit. Should it decide to stay, it has to choose whether to serve only the domestic market or to serve the domestic market and also export. Exporting requires it to bear the fixed cost, $f_{x}$, and the variable cost, $\tau$. After deciding on its strategy, which includes the export status, a firm posts vacancies in order to be matched with $h$ workers. The search and matching process in the labor market implies that the cost of being matched with these workers is $b_{j} h$ in country $j$. After hiring the workers a firm engages in multilateral bargaining with them in the manner proposed by Stole and Zwiebel $(1996 a, b)$. This bargaining game yields a solution in which the wage rate equals a fixed fraction of revenue per worker, where this fraction depends on the elasticity of substitution between brands of the differentiated product. Anticipating this equilibrium wage structure, a profit-maximizing firms chooses employment $h$ up to the point at which it pays a wage rate equal to the hiring cost, $b_{j}$. As a result, similar to the simpler model discussed in Section 2, all firms pay the same wage rate - independently of their productivity or export status - despite the fact that wages are determined in a different manner. The domestic cutoff, $\theta_{d}$, and the export cutoff, $\theta_{x}$, are determined in the same way as in Section 2 , and the free-entry condition, i.e., that expected profits equal the entry cost, $f_{e}$, is also similar (see (2)).

Helpman and Itskhoki (2009) use this general equilibrium model of two countries to derive results on the impact of labor market and trade frictions on trade flows, productivity, welfare and unemployment. In this framework country $j$ 's unemployment rate equals the weighted average of its sectoral rates of unemployment, $1-x_{0}$ and $1-x$, expressed as

$$
u_{j}=\frac{N_{0 j}}{\bar{N}_{j}}\left(1-x_{0 j}\right)+\frac{N_{j}}{\bar{N}_{j}}\left(1-x_{j}\right),
$$

where $N_{0 j}$ is the number of workers searching for jobs in the homogeneous sector, and $N_{j}$ is the number of workers searching for jobs in the differentiated sector, and $\bar{N}_{j}=N_{0 j}+N_{j}$ is the total number of workers in this country.

First, a larger fraction of differentiated-sector firms export in country $B$, which has the smaller hiring cost (i.e., $b_{A}>b_{B}$ ). Moreover, country $B$ exports differentiated products on net and imports homogeneous goods. ${ }^{15}$ In addition, the share of intra-industry trade is smaller

\footnotetext{
${ }^{15}$ Davidson, Martin and Matusz (1999) were the first to point out that across-country differences in labor market frictions of the Diamond-Mortensen-Pissarides type can be a source of comparative advantage.
} 
the larger the ratio $b_{A} / b_{B}$ is, i.e., the larger the proportional difference in the differentiated sectors' hiring costs.

Second, differentiated-sector TFP is higher in every trade equilibrium than in autarky, as in Melitz (2003). And if the productivity $\theta$ is distributed Pareto, then TFP is higher in country $B$ 's differentiated sector than in $A$ 's. Sectoral productivity in the differentiated sector is sensitive to labor market frictions. In particular, a decline in $a_{j}$ raises this productivity in country $j$ but reduces it in the trade-partner country. In other words, if labor market frictions decline in the differentiated sector of a country this country enjoys higher total factor productivity, but this generates a negative productivity shock in the trade-partner country.

Third, despite the labor market frictions, both countries gain from trade, but a country's welfare level depends on labor market frictions in its trade-partner country in addition to its own. On the one hand, a reduction in labor market frictions in country $j$ 's differentiated sector raises its welfare and reduces the welfare level of its trade partner. This negative transmission is related to the negative transmission of productivity discussed above. On the other hand, a simultaneous proportional reduction in labor market frictions in the differentiated sectors of both countries raises welfare in both of them. This suggests that labor market reforms may turn into beggar-thy-neighbor policies, unless they are coordinated across countries. In addition, a reduction in labor market frictions in country $j$ at a common rate in both sectors raises its welfare and does not affect the welfare level of its trade partner. And a reduction of trade impediments raises welfare in both countries.

Fourth, in a symmetric world economy in which $a_{0}$ is the same in both countries, and so is $a$, a reduction in labor market frictions in the differentiated sectors at the same rate in both countries reduces aggregate unemployment if and only if $a$ is sufficiently small relative to $a_{0}$, and raises unemployment otherwise. In this case lower frictions reduce the sectoral rates of unemployment (by rasing $x_{0}$ and $x$ ), but they also reallocate labor to the differentiated sector, which raises aggregate unemployment when $a>a_{0}$ (see (5)). The former effect dominates when $a$ is sufficiently small relative to $a_{0}$, and unemployment necessarily declines when $a<a_{0}$. Moreover, a reduction in labor market frictions at a common rate in both sectors and both countries reduces aggregate unemployment. Finally, a reduction in trade impediments - including the opening of trade - raises aggregate unemployment if and only if $a>a_{0}$, because it reallocates labor toward the differentiated sector and trade does not impact the sectoral rates of unemployment.

When the countries are not symmetric, richer patterns of unemployment emerge in equilibrium. In particular, the rate of unemployment can be higher in either country $A$ or country $B$. For example, the rate of unemployment may rise in both countries in response to higher labor market frictions in country $A$, or it may rise in $B$ and decline in $A$.

It follows from this analysis that while trade may raise unemployment (which happens 
when labor market frictions are higher in the differentiated sector), it always raises welfare. Moreover, unemployment does not reflect welfare in the cross section; the country with higher welfare may have higher or lower unemployment. And importantly, uncoordinated reductions of labor market frictions in one country only, while benefitting the reforming country, hurt the trade partner.

The last result has a bearing on the debate about labor market policies in the EU. In October 1997, the EU amended its governing agreement by the Treaty of Amsterdam, which made employment policies a priority. In November 1997, the extraordinary European Council meeting in Luxembourg launched the European Employment Strategy. Two and a half years later, during the European Council meeting in Lisbon in March 2000, the heads of state launched the Lisbon Agenda, designed for the EU "...to become the most competitive and dynamic knowledge-based economy in the world." What exactly should the European Union do in order to achieve these objectives? As an example, the UK has been concerned with lack of labor market flexibility in countries such as France and Spain, and it has been promoting labor market reforms. Our results suggest that unilateral labor market reforms in, say, France, may not benefit the UK. But coordinated reductions in labor market frictions can benefit every country.

\section{Inequality}

In the previous section wages differ across sectors but not across firms or workers within a sector. Moreover, all firms employ the same composition of workers, who are perfect substitutes for each other. In the data, however, substantial differences exist in workforce composition across firms of different size, there is large variation in wages of workers with the same observed characteristics, larger firms pay higher wages, and exporters pay an export wage premium (that is, they pay higher wage than a nonexporter with the same productivity would pay). As a result, there is substantial wage inequality within industries, and this inequality varies across sectors. To address these issues Helpman, Itskhoki and Redding (2010) extend the analytical framework from the previous section and provide an analysis of the determinants of both unemployment and wage inequality within industries. In what follows I report some of their findings, focusing on equilibrium outcomes within a sector for the case of a single type of risk-neutral worker. ${ }^{16}$

Instead of workers being identical, as in the previous section, now assume that workers are perfect substitutes for each other in the homogeneous product sector, but that in the differentiated product sector they are identical ex-ante but not ex-post. In particular, suppose that when a worker is matched with a firm in the differentiated sector the quality of the match

\footnotetext{
${ }^{16}$ Helpman, Itskhoki and Redding (2010) also discuss the case of multiple types of workers, risk-averse workers, and general equilibrium interactions.
} 
is random, with $a$ representing the realized ability of the worker on the job in the firm. The ability level, $a$, is drawn from the Pareto distribution $F(a)=1-\left(a_{\min } / a\right)^{k}$ for $a \geq a_{\min }>0$, $k>1$, and these draws are independent across firms and individuals. Importantly, the ability level, $a$, is observed neither by the individual worker nor by his employer. In this event, all firms have the same composition of workers if they do not screen job candidates. But because, as will soon become clear, the ability distribution of the workforce impacts a firm's overall productivity, firms have an incentive to screen job candidates. To this end they have an imperfect screening technology which allows a firm to determine only whether the ability of a worker is above or below a threshold, $a_{c}$, but this technology is costly to implement, with the cost being $c a_{c}^{\delta} / \delta$ units of the homogeneous good. That is, higher ability thresholds are more costly to administer, but the higher the threshold $a_{c}>a_{\min }$ is, the higher is the average ability of the firm's workforce if it retains only workers above the screening threshold. ${ }^{17}$

For the following analysis also assume that the distribution of a firm's productivity is Pareto, given by $G(\theta)=1-\left(\theta_{\min } / \theta\right)^{z}$ for $\theta \geq \theta_{\min }>0$ and $z>1$, and that the production function is

$$
y=\theta h^{\gamma} \bar{a}, \quad 0<\gamma<1
$$

instead of (1), where $\bar{a}$ is the average ability of the firm's workers. In this specification output is larger the more productive the firm is, the higher is the average ability of its employees, and the more workers it employs. An important feature of this production function is complementarity between the ability levels of workers; the higher the average ability of the workforce, the higher is the marginal product of a worker. Every employee contributes to output both through the employment level, $h$, and through the average ability, $\bar{a}$. For this reason adding a worker with below average ability to the pool of employees raises output through $h$ but reduces it through $\bar{a}$. For a given pool of potential employees with whom a firm is matched, output rises with the threshold $a_{c}$ when $\gamma k<1$. In other words, in this case dropping the least able workers raises output because the gain in average ability $\bar{a}$ exceeds the loss in the employment level $h$. Under the circumstances a firm has an incentive to engage in costly screening.

In this setup the cost of matching with $\ell$ workers is $b \ell$. After being matched with $\ell$ workers a firm chooses a screening threshold $a_{c} \geq a_{\min }$ and hires only workers with ability $a$ above the threshold. The resulting employment level is $h=\left(a_{\min } / a_{c}\right)^{k} \ell$ and the firm bargains with the $h$ workers over wages. At this stage the firm knows that every worker has ability above $a_{c}$, but it does not know the ability level of each individual worker. This leads to an equilibrium wage which is the same for every worker in the firm. Stole-Zwiebel multilateral bargaining implies that the wage rate is again a fraction of the revenue per worker, except that now this fraction depends both on the elasticity of substitution between brands of the differentiated

\footnotetext{
${ }^{17}$ The Pareto distribution implies that the average ability of these workers is $\bar{a}=k a_{c} /(k-1)$.
} 
product and on the parameter $\gamma$ from the production function (6).

As in Melitz (2003), profit-maximizing firms sort into sales strategies by productivity, as described in Figure 1: the least productive firms exit, the most productive firms export, and firms with productivity between $\theta_{d}$ and $\theta_{x}$ serve only the domestic market. Unlike Melitz (2003), however, wages differ across firms. In equilibrium

$$
\frac{w(\theta) h(\theta)}{\ell(\theta)}=b
$$

where $w(\theta)$ is the wage rate in a firm with productivity $\theta, \ell(\theta)$ is the number of workers it chooses to match with, and $h(\theta)$ is its employment level. Consistent with the data, moreproductive firms match with more workers, employ more workers, have a better workforce composition (i.e., they are more selective in hiring), and pay higher wages, including an export wage premium. Risk-neutral workers are indifferent between being matched with a high- or low-productivity firm, because conditional on being matched, the expected wage is the same in all firms. That is, a worker matched with a firm of productivity $\theta$ is hired with probability $h(\theta) / \ell(\theta)$, and if hired he receives the wage rate $w(\theta)$, which implies that the expected wage rate equals $b$.

Now a worker can be unemployed for two reasons. First, he may not be matched with a firm. Second, even if matched with a firm, his match-specific ability a may fall below the firm's cutoff $a_{c}$, in which case he is not hired. As a result the sectoral rate of unemployment is not $1-x$ but rather $1-\sigma x$, where $\sigma$ is the industry's average hiring rate $h(\theta) / \ell(\theta)$.

In this framework sectoral wage inequality is larger in the open economy than in the closed economy, as long as only a fraction of firms export (i.e., as long as $\theta_{x}>\theta_{d}$ ). When all firms export, wage inequality in the open economy is the same as in the closed economy. This implies that rising trade costs may generate nonmonotonic responses of wage inequality. In particular, wage inequality within an industry may rise initially with the trade cost and decline with further increases in the trade cost. This is necessarily the case when the fixed export cost $f_{x}$ rises, but may also be the case when the variable trade cost $\tau$ rises. ${ }^{18}$

When $\omega$ is invariant to trade (as in the previous section), sectoral unemployment is strictly higher in the open economy than in the closed economy, because exporters are more selective in their hiring than nonexporters. ${ }^{19}$ Nevertheless, every worker's ex-ante welfare is higher in the open economy than in the closed economy. In other words, workers gain from trade despite the fact that they face more income risk and higher unemployment in the open

\footnotetext{
${ }^{18}$ It is also possible for wage inequality to be rising in the variable trade cost everywhere when $f_{x}>f_{d}$, but wage inequality as a function of the variable trade cost has an inverted- $U$ shape when $f_{x}<f_{d}$.

${ }^{19} \mathrm{I}$ focus here on the case of a constant $\omega$. In many cases, however, $\omega$ changes with trade, and then a general equilibrium analysis is required in order to assess the impact of trade on workers' expected income. See Helpman, Itskhoki and Redding (2010) for a discussion of such general equilibrium feedbacks.
} 


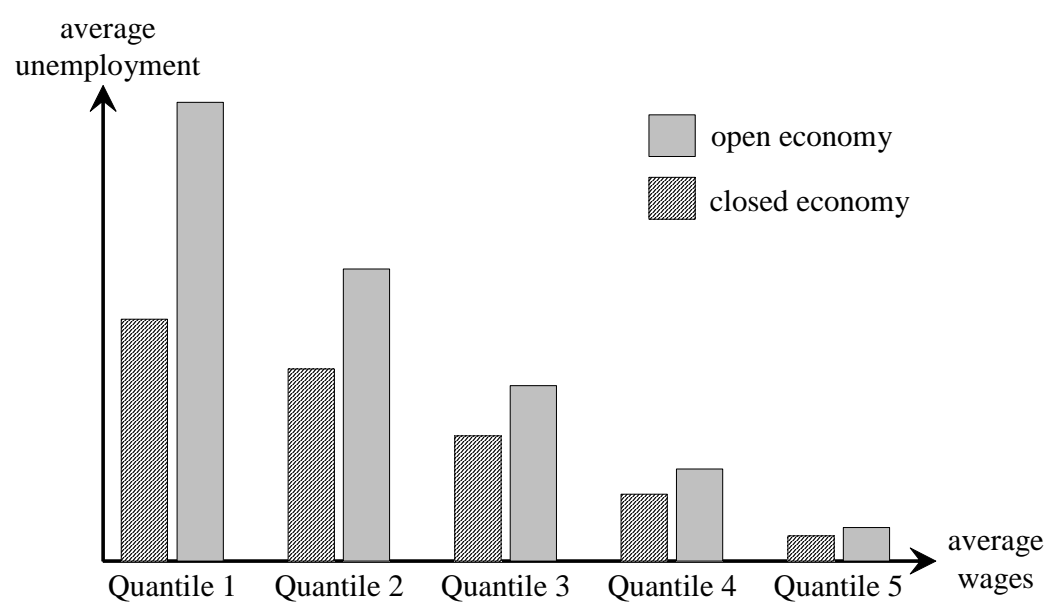

Figure 2: Average unemployment across wage quantiles

economy. $^{20}$

Interestingly, trade differentially impacts matches with different abilities $a$. Helpman, Itskhoki and Redding (2009) show that the rate of unemployment of workers with matchspecific ability $a, u(a)$, is decreasing in $a$ for all $a \geq a_{d}$. When an economy opens to trade, unemployment rises for every ability level, but it rises most for medium-ability workers and least for high-ability workers.

The distribution of wages conditional on $a$, measured in units of the homogeneous good, implies that both average wages and wage inequality are higher for workers with higher ability. But trade affects wage distributions differently for workers with different abilities. For low values of $a$, the conditional wage distribution is the same in autarky and in the trade equilibrium. For high values of $a$, the conditional wage distribution in the open economy first-order stochastically dominates the conditional wage distribution in the closed economy. And for intermediate values of $a$, the conditional wage distribution in the open economy is first-order stochastically dominated by the wage distribution in the closed economy. It follows that medium-ability workers are the least fortunate when trade opens up, both in terms of wage gains and unemployment. This results from the fact that trade leads to the loss of job opportunities for workers with intermediate ability levels in high-productivity firms, which become exporters. The lowest-productivity workers are not employed by high-productivity firms in the closed as well as open economies, while the highest-productivity workers are employed by high-productivity firms in both the closed and open economies, and therefore the middle range of abilities suffers a relative disadvantage from trade.

Our results on the variation in unemployment and wage distributions across workers with

\footnotetext{
${ }^{20}$ This result also holds when workers are risk-averse, but the relative measure of risk-aversion is low.
} 
different match-specific ability levels imply that average wages and unemployment rates are negatively correlated in the cross section. Figure 2 illustrates this relationship in a closed and open economy across quantiles of the wage distribution (with the same number of workers in every quantile); when the economy opens to trade, the largest increase in unemployment takes place among workers with the lowest average wages.

International trade makes trading countries interdependent, which impacts unemployment and inequality. New research that emphasizes firm heterogeneity within industries provides a suitable framework for studying the determinants of trade and foreign direct investment, as well as interdependence across countries in rates of unemployment and income inequality. I have reviewed in this paper recent research that incorporates labor market frictions and worker heterogeneity into this framework in order to address these issues. The new models capture important features of the data and provide a suitable framework for studying trade and labor market policies. 


\section{References}

[1] Aw, Bee-Yan, Sukkyun Chung and Mark J. Roberts (2000), "Productivity and Turnover in the Export Market: Micro-level Evidence from the Republic of Korea and Taiwan (China)." World Bank Economic Review 14, pp. 65-90.

[2] Balassa, Bela (1966), "Tariff Reductions and Trade in Manufactures among the Industrial Countries." American Economic Review 56, pp. 466-473.

[3] Balassa, Bela (1967), Trade Liberalization Among Industrial Countries (New York: McGraw-Hill Book Company).

[4] Baldwin, John R. and Wulong Gu (2003), "Export Market Participation and Productivity Performance in Canadian Manufacturing." Canadian Journal of Economics 36, pp. 634-657.

[5] Bernard, Andrew B., Jonathan Eaton, J. Bradford Jensen, and Samuel Kortum (2003), "Plants and Productivity in International Trade." American Economic Review 93, pp. 1268-1290.

[6] Bernard, Andrew B., J. Bradford Jensen and Robert Z. Lawrence (1995), "Exporters, Jobs, and Wages in U.S. Manufacturing, 1976-1987." Brookings Papers on Economic Activity, Microeconomics, pp. 67-119.

[7] Bernard, Andrew B. and J. Bradford Jensen (1999), "Exceptional Exporter Performance: Cause, Effect, or Both?" Journal of International Economics 47, pp. 1-25.

[8] Bernard, Andrew B. and J. Bradford Jensen (2004), "Why Some Firms Export." Review of Economics and Statistics 86, pp. 561-569.

[9] Bernard, Andrew B., J. Bradford Jensen, Stephen J. Redding and Peter K. Schott (2007), "Firms in International Trade." Journal of Economic Perspectives 21, pp. 105-130.

[10] Clerides, Sofronis K., Saul Lach and James R. Tybout (1998), "Is Learning by Exporting Important? Micro-Dynamic Evidence form Colombia, Mexico, and Morocco." Quarterly Journal of Economics 113, pp. 903-947.

[11] Cuñat, Alejandro and Marc Melitz (2007), "Volatility, Labor Market Flexibility, and the Pattern of Comparative Advantage," NBER Working Paper No. 13062.

[12] Das, Sanghamitra, Mark J. Roberts and James R. Tybout (2007), "Market Entry Costs, Producer Heterogeneity, and Export Dynamics," Econometrica 75, pp. 837-873. 
[13] Davidson, Carl, Lawrence Martin and Steven Matusz (1999), "Trade and Search Generated Unemployment," Journal of International Economics 48, pp. 271-299.

[14] Delgado, Miguel A., Jose C. Fariñas, and Sonia Ruano (2002), "Firm Productivity and Export Markets: A Non-Parametric Approach." Journal of International Economics 57, pp. 397-422.

[15] Diamond, Peter A. (1982a), "Demand Management in Search Equilibrium." Journal of Political Economy 90, pp. 881-894.

[16] Diamond, Peter A. (1982b), "Wage Determination and Efficiency in Search Equilibrium." Review of Economic Studies 49, pp. 217-227.

[17] Eaton, Jonathan, Samuel Kortum and Francis Kramarz (2004), "Dissecting Trade: Firms, Industries, and Export Destination," American Economic Review (Papers and Proceedings) 94, pp. 150-154.

[18] Helpman, Elhanan (2006) "Trade, FDI, and the Organization of Firms." Journal of Economic Literature XLIV: 589-630.

[19] Helpman, Elhanan and Oleg Itskhoki (2009), "Labor Market Rigidities, Trade and Unemployment," Review of Economic Studies, forthcoming.

[20] Helpman, Elhanan, Oleg Itskhoki and Stephen Redding (2009), "Unequal Effects of Trade on Workers with Different Abilities," Journal of the European Economic Association, forthcoming.

[21] Helpman, Elhanan, Oleg Itskhoki and Stephen Redding (2010), "Inequality and Unemployment in a Global Economy," Econometrica, forthcoming.

[22] Helpman, Elhanan, Marc J. Melitz and Stephen R. Yeaple (2004), "Export versus FDI with Heterogeneous Firms," American Economic Review 94, pp. 300-316.

[23] Helpman, Elhanan, Marc Melitz and Yona Rubinstein (2008), "Trading Partners and Trading Volumes." Quarterly Journal of Economics 123, pp. 441-487.

[24] Manova, Kalina (2008), "Credit Constraints, Equity Market Liberalizations and International Trade," Journal of International Economics 76, pp.33-47.

[25] Manova, Kalina (2009), "Credit Constraints, Heterogeneous Firms and International Trade," mimeo, Stanford University.

[26] Melitz, Marc J. (2003), "The Impact of Trade on Intra-Industry Reallocations and Aggregate Industry Productivity," Econometrica 71, pp. 1695-1725. 
[27] Mortensen, Dale T. and Christopher A. Pissarides (1994), "Job Creation and Job Destruction in the Theory of Unemployment," Review of Economic Studies 61, pp. 397-415.

[28] Nunn, Nathan (2007), "Relationship-Specificity, Incomplete Contracts, and the Pattern of Trade," Quarterly Journal of Economics CXXII, pp. 569-600.

[29] Pavcnik, Nina (2002), "Trade Liberalization, Exit, and Productivity Improvements: Evidence from Chilean Plants." Review of Economic Studies 69, pp. 245-276.

[30] Pissarides, Christopher A. (2000), Equilibrium Unemployment Theory (Cambridge, MA: The MIT Press, second edition).

[31] Roberts, Mark J. and James R. Tybout (1997), "The Decision to Export in Colombia: An Empirical Model of Entry with Sunk Costs." American Economic Review 87, pp. 545-564.

[32] Trefler, Daniel (2004), "The Long and Short of the Canada-U.S. Free Trade Agreement." American Economic Review 94, pp. 870-895.

[33] Tybout, James R. and M. Daniel Westbrook (1995), "Trade Liberalization and the Dimensions of Efficiency Changes in Mexican Manufacturing Industries." Journal of International Economics 39, pp. 53-78.

[34] Stole, Lars A. and Jeffrey Zwiebel (1996a), "Organizational Design and Technology Choice under Intrafirm Bargaining," American Economic Review 86, pp. 195-222.

[35] Stole, Lars A. and Jeffrey Zwiebel (1996b), "Intra-Firm Bargaining under Non-Binding Contracts," Review of Economic Studies 63, pp. 375-410.

[36] World Trade Organization (2008), World Trade Report 2008: Transnational Corporations, and the Infrastructure Challenge (Geneva: World Trade Organization). 